Still there appears no justification for the lengths to which the stamp of constitutional approval has been applied simply because the defendant hired his own lawyer. One would think that the Sixth Amendment guaranteed sober counsel. The Court of Appeals for the Tenth Circuit has held otherwise:

"The most that can be said for this testimony is that it establishes that appellee's counsel drank throughout the trial and that he was under the influence of intoxicating liquor to a greater or less degree during the whole trial. But what of it? Appellee employed him; ...." ${ }^{4}$

\title{
EXTENSION OF RELIEF FOR UNILATERAL MISTAKE
}

The modern trend of the law of mistake in contracts is toward wider relief for both mutual and unilateral error. For most types of unilateral mistake, rescission is opposed by adherents of the rigidly "objective" view of mistake in contracts. Occasionally courts hesitate to give relief for any type of unilateral error, although paying lip service to the doctrine permitting rescission under certain conditions. In United States v. Jones, ${ }^{x}$ the War Assets Administration made a special offering of certain universal gear joints declared as surplus property by the U. S. Maritime Commission and fully described in the declarations. The WAA asked for bids upon the property, and, receiving none, later put it up on a negotiated sale basis. Jones, the defendant, asked an employee of the WAA if there were jeep motors for sale and was told that there were but that they might only be purchased as part of an entire odd lot. In the lot Jones recognized the universal gear joints as equipment worth perhaps $\$ 60, \infty 00$. Jones knew that the agent of the government was not aware of the nature or value of the equipment. By negotiation he lowered the asking price from $\$ 250$ to $\$ 75$ and bought at the latter price. Upon learning of its mistake the government refused delivery and brought suit for rescission of the contract.

The court admitted that rescission was proper on this state of facts, applying the test of whether the mistake was one as to the identity of the subject matter or merely as to a collateral characteristic. ${ }^{2}$ The metaphysical character and inutility of this test have misled courts into dubious and occasionally startling

4 Hudspeth v. McDonald, I20 F. 2d 962, 967 (C.A. roth, I94I). The district court had found that the defendant had had no effective assistance of counsel as required by the Sixth Amendment. McDonald v. Hudspeth, 4I F. Supp. 182 (Kan., I94I). Compare Wade v. Mayo, 334 U.S. 672 ( 1948 ), where the district court's finding that the defendant was handicapped by lack of counsel was upheld as "not clearly erroneous." The district court's finding in the McDonald case appears to be clearly "not clearly erroneous."

I I76 F. 2 d 278 (C.A. 9th, I949).

2 Adoption of this test rather than the modern fundamental assumption test might indicate the court'sdesire torestrict relief for mistake, for, as pointed out in 5 Williston, Contracts $\$$ I $570 \mathrm{~A}$ (rev. ed. 1937), "under the modern basic assumption test the way is opened for further development of the law toward greater extension of relief. ..." The court cites Frank's concurring opinion in Ricketts v. Pennsylvania R. Co., 153 F. 2d 757 (C.A. 2d, I946), but is noncommital as to his recommendation of extension of relief for unilateral mistake. I76 F. $2 \mathrm{~d} 278$, at $286 \mathrm{n} .4$ (C.A. 9th, 1949). 
reasoning. ${ }^{3} \mathrm{~A}$ test which bases relief upon whether or not the mistake concerned a fundamental assumption of one or both of the parties is the best replacement for the identity-of-subject-matter test. ${ }^{4}$ A leading English case, Bell v. Lever Bros., ${ }^{5}$ illustrates the different results obtainable under the two tests. In order to terminate service contracts for a term of years with the defendants, Lever Bros., $L t d$., entered into termination agreements providing for additional compensation. Later, Lever Bros. discovered that the defendants' acts while under the service contracts would have justified termination of the contracts without compensation. In an action for rescission of the termination agreements the jury found that Lever Bros. would have so terminated the contracts had it known of the defendants' breach of contractual duty. A majority of the court held that the mistake was not one as to the identity of the subject matter but merely one as to quality (viz., that the service contracts were no longer binding on Lever Bros.). "The contract released is the identical contract in both cases, and the party praying for release gets exactly what he bargains for. It seems immaterial that he could have got the same result in another way." ${ }^{\prime 6}$ But this is precisely what would be material under the fundamental assumption test, used successfully by many courts, ${ }^{7}$ under which rescission would have been granted. Although in the Jones case the court did find a mistake sufficient to justify rescis-

3 King Co. v. Aldrich, $8 x$ N.H. 42, I2I Atl. 434 (x923). Plaintiff bought diseased hogs from the defendants, both parties knowing that the hogs were to be used for food, but neither knowing that they were diseased and so useless for that purpose. The court said there was no contract because of mutual mistake since diseased hogs are really not the same hogs as healthy ones and therefore not the ones the parties had in mind. 5 Williston, Contracts $\$ \times 569$ (rev. ed. 1937), shows the fallacy of this argument to be that the hogs were specific and identified when delivered, if not before.

In addition to the castuistry often entailed in its application, the identity-of-subject-matter test fails to take account of the policy to be served in mistake cases. Parties are undoubtedly surprised when a court bases its decision on whether the mistake concerned the identity of the subject of their transaction. They are more likely concerned with notions of fairness and of unjust enrichment and impoverishment resulting from mistake. Courts should be concerned with the conditions for healthy trading in our economy, one of which requires informed buyers and sellers. The identity test is unrelated to either consideration.

45 Williston, Contracts $\S$ I544 (rev. ed. I937); Rest., Contracts $\S 502$ (1932); Williston, Rescission of a Contract for Mutual Mistake of Fact, 35 Harv. L. Rev. 757 (I922). Sharp, Notes on Contract Problems and Comparative Law, 3 Univ. Chi. L. Rev. 277, at 283 (x935), is the best statement of the fundamental assumption test: "[W] here the parties to a transaction think of a fact as humanly certain, that is, possessing very high probability, and as a result make their transaction; and it is impossible to suppose that they were taking the risk of circumstances turning out otherwise, the mistake, if prejudicial, will be a defense to a contract action or suit, or a ground for affirmative relief." This test reflects the policy considerations mentioned in note 3 supra.

5 [1932] App. Cas. I6r.

${ }^{6} \mathrm{Tbid}$. at 223 (Lord Atkin).

7 In Lindeberg v. Murray, II 7 Wash. 483, 20I Pac. 759 (I92I), the buyer of a large number of shares of stock in a bank was allowed rescission on the ground that the transaction had been entered into under a mutual mistake as to the assets of the corporation. Rosenblum v. Manufacturers Trust Co., 270 N.Y. 79, 200 N.E. 587 (I936); Jones v. Metzger, I32 Miss. 247, 96 So. I6I (I923); Jackman v. Northwestern Trust Co., 87 Ore. 209, I70 Pac. 304 (Igr8). 
sion even under the identity test, it denied relief upon its construction of the Surplus Property Act of $1944 .^{8}$ The court's reasoning as to the effect of the statute upon mistake is unconvincing: "The Government was not aiming to drive hard bargains with the purchasers of this surplus property. It was not seeking to sell, at a profit, in competition with private industry, or to break even." "The court adds: "Nowhere in the statement of objectives is recovery of cost or value mentioned as a basis for disposition." But one of the purposes listed in the objectives is, "except as otherwise provided, to obtain for the Government, as nearly as possible, the fair value of surplus property upon its disposition." Io

The court may have been influenced by its conception of the relative bargaining positions of the parties. Enforcement of contracts despite unilateral mistake is sometimes defended on the ground that the parties were equals in bargaining position. ${ }^{x}$ The weakness of the court's argument upon the construction of the statute leads to the suspicion that, despite its remarks on the subject, it was loath to allow rescission on the basis of unilateral mistake. Such misgivings are common.

Apparently the court adopts the prevalent "objective" view of unilateral mistake: that to entitle the mistaken party to relief his mistake must have been known to the other party. ${ }^{\mathrm{r} 2}$ Relief rests upon the ethical ground that a person ought not to profit at the expense of another whom he knows to be making a costly error. Perhaps because actual knowledge of the mistake by the nonmistaken party is difficult to show, relief is now usually given where the mistake

${ }^{8} 5^{8}$ Stat. 765 (1944), 50 U.S.C.A. $\$$ I6II et seq. (App., x944). The court said: "Absent actionable fraud, the War Surplus Property Act of 1944 . . . has made the sale to Jones immune against an attack grounded on lack of authority or mistake."

9 "To use Hotspur's phrasing, the Government was not 'in the way of bargain' caviling 'on the ninth part of a hair.' Rather, like him, in dealing with the property, the Government, in its largess, was willing to

'Give thrice so much. ..

To any well-deserving friend'

Shakespeare, I Henry IV, Act III, Sc. I." I76 F. 2d 278, 290 (C.A. 9th, 1949).

Query whether such sentiments are aptly applied to this defendant who consciously took advantage of the WAA agent's mistake to obtain over $\$ 60,000$ in goods for $\$ 75$.

${ }^{\prime 0}$ War Surplus Property Act of 1944,58 Stat. 766 ( $t$ ) (1944), 50 U.S.C.A. \& 1612 (t) (App. x944).

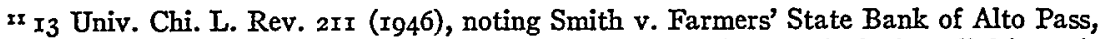
390 Ill. 374,6 I N.E. 2d 557 (I945). The result here is upheld because it denies relief for unilateral mistake where the parties were equal in bargaining power. While there may be a tendency to grant relief where there is a striking disparity in bargaining power, there seems no reason for the contrary proposition that relief should be denied where bargaining positions are equal. This doctrine, limited to mistakes in ownership, is inapplicable here also because Jones was clearly the superior in bargaining power. He had knowledge the WAA clerk did not have.

${ }_{22} 5$ Williston, Contracts $\S$ I573 (rev. ed. I937); I Page, Contracts $\S 279$ (2d ed. x920). In allowing rescission because of the nonmistaken party's knowledge of the mistake, the "objectivists" permit a bit of "subjectivity" to creep into their formula. The concession is made because the situation so closely resembles fraud. 
was so glaring that it should have been known (palpable mistake).13 However, the English rule as stated in Smith v. Bughes ${ }^{14}$ requires not only that the other's mistake be known to the nonmistaken party, but that the nonmistaken party know that the other believes him to be promising what in fact he is not. The distinction is shown by Anson's Dresden China cases.15 The seller knows that the buyer thinks he is getting Dresden china when in fact he is not. There is no rescission; caveat emptor governs. But if the seller knows that the buyer thinks that the china is offered as Dresden when actually it is not, rescission is granted. Probably the reason for this distinction is that in the first case the buyer is getting the china for the price of ordinary china and may be trying to take advantage of what he thinks is a mistake by the seller while in the second situation the buyer is innocent of such intent and is getting ordinary china for the price of Dresden.

Not all American courts follow the "objective" theory of unilateral mistake when to do so would cause unjustifiable hardship. In Rosenblum v. Manufacturers Trust $C o{ }^{16}$ plaintiff's deceased husband had named her as beneficiary of a life insurance policy. After the birth of their child he replaced plaintiff with the defendant trust company as trustee for his children because he thought their child would thus share equally with his two children by a prior marriage in the benefits of the policy. But he was mistaken as to the trust arrangement and only the defendant children by the former marriage shared. Defendants had no knowledge or reason to know of this error. Rescission was given because unjust enrichment would otherwise result. In Schaefer v. Henze, ${ }^{27}$ an Illinois case, the party seeking relief mistakenly conveyed part of his house and lot, thinking he was conveying another strip of land, in order to correct a deed between the nonmistaken party and a third person. The nonmistaken party, certain of the footage he wanted, did not know or have reason to know of the mistake. The court granted rescission. Not to have done so would have been an especially marked injustice since the consideration was merely nominal. There is a scattering of other cases to the same effect. ${ }^{18}$

${ }_{3}$ In Moffett, Hodgkins \& Clarke Co. v. Rochester, x78 U.S. 373 (Igoo), there was a mistake in a bid submitted to the city by a contractor, and rescission was given because the difference between this bid and others was so glaring that the city ought to have known of the mistake. Gross v. Stone, I73 Md. 653, I97 Atl. I37 (I938); Geremia v. Boyarsky, I07 Conn. 387, I40 Atl. 749 (r928); Holmes v. Cameron, 267 Pa. 90, rro Atl. 8r (I920); City of New York v. Dowd Lumber Co., I40 App. Div. 358, I25 N.Y. Supp. 394 (I910); Singer v. Grand Rapids Match Co., II7 Ga. 86, 43 S.E. 755 (I903); see Saline County v. Thorpe, 337 Mo. II40, 88 S.W. 2d $x 83$ (I935). Rest., Contracts $\$ 5 \circ 3$, Comment a, Illustration I (I932).

${ }_{4}$ [I87x] L.R. 6 Q.B. 597.

Is Anson, Contracts $156-57$ (I8th ed. 1937).

${ }^{16} 270$ N.X. 79, 200 N.E. $5^{87}$ (1936).

${ }^{17} 337$ Ill. $4 \mathrm{I}$, 168 N.E. 625 (1929).

${ }^{88}$ In re Clark's Estate, 233 App. Div. 487, 253 N.Y. Supp. 524 (I93I); Murray v. Sanderson, 62 Wash. 477 , II4 Pac. 424 (IgII); see Seidman v. New York Life Insurance Co., 162 N.Y. Misc. 560, 296 N.Y. Supp. 55 (I937); Brown v. Bradley, 259 S.W. 676 (Tex. Civ. App., I924); Morgan v. Owens, 228 III. 598, 8 I N.E. II 35 (I907). 
The party seeking relief may be able to establish unilateral palpable mistake and yet fail on the ground that it is impossible to restore the parties to status quo. ${ }^{\mathrm{Ig}}$ Perhaps this rule should be modified to allow rescission if the mistake was palpable. At any rate, where exact restoration of the status quo is impossible courts should not deny rescission if money damages can approximate this result. This would have led to a more satisfactory disposition of Lang v. Borne, ${ }^{20}$ where rescission was denied on the alternative ground that plaintiff had cut timber from the land he wished to reconvey. In suits for rescission for fraud courts have left more leeway in defining restoration to the status quo. ${ }^{2 x}$ Relief would be granted more often in cases of unilateral mistake if the same liberality of definition were observed there. Although the courts tend to deny rescission where the agreement is executed, ${ }^{22}$ mere execution does not entail that irreparable change of position which alone ought to bar such relief. Thus the party seeking relief in Brown v. Lamphear ${ }^{23}$ meant to reserve the right to a spring in a conveyance of land but by mistake failed to do so. The party resisting relief did not know that the spring existed. The resisting party was given the option of accepting reformation or rescission. And in Goodrich v. Lathrop ${ }^{24}$ a drop in the value of the land during the time the party asking rescission was in possession was no bar to relief in the absence of evidence of physical deterioration. The court remarked that it had the power to make just restitution if rescission was granted.

Courts commonly require for relief in unilateral mistake cases that the party seeking relief must not have been negligently mistaken. ${ }^{25}$ However, negligence

19 America Land Co. v. City of Keene, 4 I F. 2 d 484 (C.A. Ist, I930); Howell v. Baker, 106 N.J. Eq. 434, I5 Atl. II7 (1930); Beattie v. Friddle, 229 Ky. 36I, I7 S.W. 2 d 246 (1929).

${ }^{20}{ }^{5} 6$ Fla. 605,23 So. $2 d 848$ (r 945 ).

2I Buffalo Builders Supply Co. v. Reeb, 247 N.Y. I70, I76, I59 N.E. 899, 901 (1928): "The plaintiff must restore to the defendant at least the value of the tangible chattels no longer in its possession. Restoration of the chattels themselves would give the defendant no greater benefit. Perhaps the plaintiff made some sales it would not have made if defendant had not sold his business. These circumstances do not bar the equitable remedy of rescission for wrong done. The terms upon which rescission may be granted where complete restoration of the parties to their former position is impossible rests in the sound discretion of the courts." In Heckscher v. Edenborn, 203 N.Y. 2IO, 96 N.E. 44I (I9II), the defendant parted with property and in a suit for rescission, stock representing the property was tendered him. The court said the tender was sufficient. Where a wrongdoer has so complicated matters as between him and the party seeking relief that complete restoration is impossible, it will not be demanded by the court. Mosteller v. Braham, 90 Cal. App. 715, 266 Pac. 367 (I928). In a suit for rescission of the sale of a lunchroom plaintiff was given back his money less the worth of the personal property not returned to defendant.

${ }^{22} 5$ Williston, Contracts $\$ 1580$ (rev. ed. I937).

${ }^{23} 35$ Vt. 252 (1862).

${ }_{24} 94$ Cal. 56, 29 Pac. 329 (1892). Decided under Galifornia Civil Code (Deering, I949) $\$ 3407$ which enacts substantially the common law as to restoration of the status quo.

${ }_{25}$ Jefferson County Bank v. Hansen Lumber Co., 246 Ky. 384, 55 S.W. 2 d 54 (I932); Lasier v. Mayer, 315 Ill. 362 , I46 N.E. 465 (I925); Grant Marble Co. v. Abbot, 142 Wis. 279, I24 N.W. 264 (Igro); Steinmeyer v. Schroeppel, 226 Ill. 9, 80 N.E. 564 (Ig07); Bonney v. Stoughton, I22 Ill. 536, I3 N.E. 833 (I887); Durkee v. Durkee, 59 Vt. 70, 8 Atl. 490 (I887). 
is frequently, perhaps usually, present in these cases and courts often seem to find negligence or its absence depending on the result they wish to buttress. ${ }^{26}$ If courts desire only to prevent harm to the nonmistaken party rather than to inflict punishment on the party negligently in error, why should negligence ever bar rescission?27

Consideration of the factual situation of Wallace v. McGirr, ${ }^{28}$ a British case, reveals the unsatisfactory results likely to occur by a consistent application of the doctrine denying relief for unilateral mistake. A prospective buyer carelessly inspected the wrong house and then signed a contract of sale. The seller did not know of the mistake. The court upheld the contract but without explanation refused specific performance as inappropriate, and awarded damages for the seller's expenses in the transaction. ${ }^{29}$ If the contract was valid, the seller should have been given the most adequate remedy available, specific performance. Since the remedy given has the same result as rescission coupled with reliance damages to the seller, the court's behavior may indicate an unwillingness to grant rescission for unilateral mistake, tempered by a realization of the frequent harshness of the doctrine.

When property has been transferred by mistake, mutual or unilateral, "the individual interests of property and the general interests in security of acquisitions themselves appear in a clear light, operating to create a rule protecting

${ }^{26}$ In Bibber v. Carville, ror Me. 59, 63 Atl. 303 (Igo5), plaintiff conveyed land to defendan $t$ by warranty deed. Later defendant informed plaintiff that the latter had not had title to all of the land the deed purported to convey. Defendant sued on the covenants of title and plaintiff sought injunction of the suit and rescission of the deed. Rescission was denied on the alternative ground that plaintiff's lack of reasonable care in failing to examine his title in the registry of deeds barred relief. But since defendant was probably similarly negligent, this seems a weak ground for the decision. However, the result is correct because by warranting his title to be good the plaintiff assumed the risk of loss.

It is stated in 5 Williston, Contracts $\S 1596$ (rev. ed. I937), that no generalization can be made that courts will not give rescission if the petitioner has been negligent. See Section $I 596$ n. 2 for cases where rescission was given despite negligence. I Page, Contracts $\S 275$ (Ig20), shows that the negligence "rule" is usually not invoked unless there is another factor present which would cause relief to be denied.

For a case in which the nonmistaken party had not relied on the contract but was given a windfall merely because of the other's blunder, see Steinmeyer v. Schroeppel, 226 Ill. 9, 80 N.E. $564(1907)$, discussed in Some Aspects of the Law of Mistake in Illinois, 5 Univ. Chi. I. Rev. 446, 453 (r938). The same situation and result occurred in Leonard v. Howard, 67 Ore. 203, I35 Pac. 549 (IgI3).

27 Perhaps by analogy to cases in tort the negligent party in a contract action should be forced to make reparation only for the actual harm resulting to the other from his fault. This would be more consistent with contemporary mores than a flat denial of relief. The social policy which prompts the doctrine of absolute liability without fault in torts is not operative in contract cases. Denial of relief because of negligence when it is not necessary to protect the nonmistaken relying party might be termed "absolute liability without injury." There is no intelligible policy ground to support such a doctrine.

${ }^{28}$ [I936] New Zealand L.R. 483.

29 A very similar factual situation obtained in Goodrich v. Lathrop, note 25 supra, but the court there viewed relief for such unilateral mistake as proper, and sidestepped the negligence question in remanding the cause for a new trial. 
the original owner from something like the 'loss' of things against a 'finder' who 'wrongfully,' without justification, insists on the uncompensated retention of 'accidentally acquired' (not 'deliberately given') benefits to the original owner's hurt."30

Whether or not relief should be given for unilateral mistake should be determined, even as in mutual mistake, by whether or not there has been an assumption of risk as to the mistake, negligent or not. This is accomplished by the use of the fundamental assumption test. It is important in doubtful cases that the parties be presumed to have taken the risk of the external world not conforming to the mental images upon the basis of which they contracted. This is so not only because of the presumption in favor of the validity of contracts, but because our society rewards risk-taking and speculation. ${ }^{32}$

If relief is given for unilateral mistake, the party resisting it should be given the option of accepting the contract, as reformed to express the mistaken party's true intent, or of rescission. With rescission the party resisting relief should receive damages to cover any detriment due to his reliance in good faith upon the existence of a binding obligation. ${ }^{32}$ Damages may be awarded according to the court's estimate of the injury caused and the degree of compensable reliance. Viscount Cave attempted this in Jones v. Waring. ${ }^{33}$ There Bodenham, a third party, had defrauded plaintiffs of $£_{5}, \infty 0$ by having them make payment to defendants whom he represented as financing an automobile firm of which plaintiffs were persuaded by Bodenham to become agents. Bodenham owed defendants $£_{5, \infty}$ for goods received under a hire-purchase agreement. When defendants received and cashed plaintiffs' check they returned to Bodenham the goods they had repossessed and delivered more goods. These goods underwent deterioration while in use by Bodenham. Viscount Cave, seeking to apportion the damages, voted with a minority of the court for the defendants, subject to their undertaking to return all of the money not required to cover their detriment. But the majority merely returned the money to plaintiffs, letting defendants suffer the full damages caused by the unilateral mistakes of both.

The power of the courts to apportion damages for reliance and their reluctance to do so is illustrated by Fibrosa Spolka Akcyjna v. Fairbairn Lawson Combe Barbour, ${ }^{34}$ a frustrated contract case. Historically different, frustration

${ }^{30}$ Sharp, Notes on Contract Problems and Comparative Law, 3 Univ. Chi. L. Rev. 277, 284 (1935). See Lord Sumner in Jones v. Waring, [r926] App. Cas. 670, 696, for the analysis of the "windfall" concept applied by Professor Sharp.

${ }^{3 x}$ In Aristotelian terms, the willingness to take risks is one of the factors rewarded by the rates of distribution of wealth in our society; it is part of our notion of distributive justice. Courts are concerned with corrective justice, with the enforcement of rates of distribution set up by society and not with their determination. Aristotle, Nichomachean Ethics, Bk. v, c. 2-4.

${ }^{32}$ See Paget v. Marshall, 28 Ch. D. 255, 284-85 (1884).

33 [I926] App. Cas. 670.

34 [ 1943$]$ App. Cas. 32. 
and mistake are similar analytically. ${ }^{35} \mathrm{~A}$ contract for the sale and delivery of special textile machinery to Poland was frustrated by the outbreak of war. The Polish company, having paid $f_{I, 000}$ in advance and received nothing in return, asked for the refund of its money. The previous rule as enunciated in Chandler v. Webster, ${ }^{36}$ that when a contract is frustrated the loss lies where it falls, was overruled and it was held that the English company must return the advance payment. This meant that the English company must bear any loss the frustration of the transaction might entail. Viscount Simon recognized the hardship likely to result from either rule, but stated: "It must be for the legislature to decide whether provision should be made for an equitable apportionment of prepaid moneys which have to be returned by the recipient in view of the frustration of the contract in respect of which they were paid." ${ }^{37}$ In answer to this call for aid the Law Reform [Frustrated Contracts] Act of $1943^{38}$ was passed. Under it sums paid are to be recovered, but allowances are to be made for expenses incurred in reliance on the contract by the party to whom the sums were paid and for benefits conferred prior to the time of discharge. The courts are given wide discretion to consider the particular circumstances of each case in apportioning the loss. But, as Professor Corbin states: "It did not require a Frustration of Contracts Act to confer this power upon the courts. In Chandler $v$. Webster, the court made an allocation of risks and a sub-division of losses. It has not been questioned that this was within its power. The allocation was 'overruled' because it was not regarded as the most desirable one, and a different allocation was decreed." 39 This problem in the Fibrosa case is like that in faultless mutual mistake. The solution suggested here for a case of negligent unilateral mistake is restitution minus reliance damages. Where the mistake is faultless (nonnegligent) the loss caused by it should be split since neither party is to blame. $4^{\circ}$ This resembles faultless mutual mistake. Perhaps in cases of unilateral palpable mistake there should be no reliance damages since the nonmistaken party's conduct borders upon the fraudulent.

In view of the timidity of courts in splitting damages to compensate for reliance, whether in the field of frustration or mistake, and in extending relief to

${ }^{35}$ The frustration of a contract may be viewed as a mistake by the parties as to future circumstances bearing upon their transaction. At times the fields overlap.

${ }^{6}$ [I I9०4] I K.B. 493 .

37 [I943] App. Cas. 32, at 49.

${ }^{8} 6$ \& 7 Geo. VI, c. 40 (1943).

${ }^{39}$ Frustration of Contract in the United States, 29 J. Comp. I.eg. \& Int. L. 8, n. I9 (I947).

$4^{\circ}$ Actually the so-called nonmistaken party is mistaken as to the other's mistake and so neither mistake can be said to have caused the loss alone. The basic notion of law is fault. Where both parties are faultless, one should not be made to bear the entire loss. fully.

In a subsequent issue of the Review the problem of damage splitting will be discussed more 
more categories of unilateral error, codification might be desirable. Experience has already been had with this solution in Germany. ${ }^{4 x}$

Although Professor Williston maintains that "a doctrine which permits the rescission of a contract on account of unilateral mistake approaches nearly to a contradiction of the objective theory of mutual assent in the formation of contracts to which the modern law seems generally to have tended," ${ }_{42}$ he concedes the workability of a "subjective" theory of mistake when coupled with an estoppel or reliance interest theory. 43 The approach to unilateral mistake suggested here would detract nothing from the many advantages of the "objective" theory but would alleviate an occasional harshness. The reasons of policy ${ }^{44}$ which dictate relief for mutual mistake apply as well to unilateral error. It seems more important that the law be determined by social policy and notions of fairness than that it be symmetrically "objective" or "subjective."

\section{HEALTH INSPECTION OF PRTVATE DWELLING WITHOUT SEARCH WARRANT}

In answer to a complaint that the halls of a private dwelling were littered with trash and garbage, a uniformed health inspector of the District of Columbia, accompanied by a police officer, asked permission to enter the dwelling and investigate. The owner refused to unlock her door and admit him, insisting that she was under no obligation to do so since neither the inspector nor the police officer had a search warrant. As a result of this refusal, the owner was convicted of a violation of the health law. ${ }^{x}$ The Supreme Court affirmed the reversal of the

4I German Civil Code $\S$ IIg (2), states that unilateral impalpable mistake entitles the mistaken party to rescission. Under Section $\mathbf{1 2 2}$ the nonmistaken party may receive damages for injuries suffered because of reliance upon the validity of the contract.

${ }^{42} 5$ Williston, Contracts $\S$ I579 (rev. ed. $x_{937}$ ).

43 Ibid., at $\$ 1536$ n. 4 .

44 Note 3 supra. While it is often said that relief is not given for unilateral mistake because the nonmistaken party relied on the existence of a binding obligation, this is true as well of the party resisting relief in a case of mutual mistake.

I "[I]t shall be the duty of every person occupying any premises, or any part of any premises, in the District of Columbia, or, if such premises be not occupied, of the owner thereof, to keep such premises or part ... clean and wholesome. If upon inspection by the Health Officer or an inspector of the Health Department, it be determined that any such part thereof, or any building, yard ... is not in such condition as herein required, the occupant or occupants of such premises or part, or the owner thereof ... shall be notified and required to place the same in a clean and wholesome condition; and in case any person shall fail or neglect to place such premises or part in such condition within the time allowed by said notice, he shall be liable to the penalties hereinafter provided. $\S 2$.

"That any person violating or aiding or abetting in violating, any of the provisions of these regulations, or interfering with or preventing any inspection authorized thereby, shall be deemed guilty of a misdemeanor, and shall, upon conviction ... be punished by a fine of not less than $\$ 5.00$ nor more than $\$ 45.00$. $\S$ I 2." District of Columbia v. Little, 339 U.S. I, 4 n. 2 (1950). 